\title{
EFFLORESCENCE INHIBITION OF ALKALI-ACTIVATED STEEL SLAG-SLAG MATERIAL BY NANO $\mathrm{SiO}_{2}$
}

\author{
PENG DU*, TONGTONG ZHOU**, "PIQI ZHAO*, "ZONGHUI ZHOU*, YU LIU***, XIN CHENG* \\ *Shandong Provincial Key Laboratory of Preparation \& Measurement of Building Materials, University of Jinan, \\ Jinan 250022, China \\ **Shandong Hi-Speed Road \& Bridge Maintenance Co., Ltd., \\ Jinan 250032, China \\ ***Shenzhen Gang Chuang Building Materials Co., Ltd., \\ Shenzhen 518052, China \\ "E-mail: mse_zhaopq@ujn.edu.cn, mse_zhouzh@ujn.edu.cn
}

Submitted March 9, 2018; accepted May 22, 2018

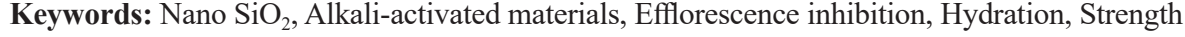

Alkali-activated materials have significant shortcomings like poor volume soundness, easy efflorescence and so on, which have restricted their application to a certain degree. Nano modification is an important approach in solving the problem. Based on the test of hydration hardening characteristics, matrix porosity and the concentration of alkali ions leaching on the surface of the alkali-activated steel slag-slag material, the effects of the nano $\mathrm{SiO}_{2}$ on matrix compaction and efflorescence inhibition were studied. The results show that when the mixing amount of the nano $\mathrm{SiO}_{2}$ was $2.0 \%$, the growth rates of the compressive strengths of the specimen at $1 \mathrm{~d}$ and $28 \mathrm{~d}$ increased by $203.71 \%$ and $39.29 \%$, respectively, when compared with the blank specimen. The nano $\mathrm{SiO}_{2}$ exerted filling and crystal nucleus effects, and a clustering fibrous $\mathrm{C}-\mathrm{S}-\mathrm{H}$ gel was generated around the nanoparticles. The matrix was compacted with an increase in the hydration products, and, as a result, the overall porosity of the matrix reduced by $7.06 \%$. Porosity improvement contributed in preventing internal alkali ions in the specimen leaching to the surface, and the ionic concentration of the leaching solution out of the specimen reduced by $32.57 \%$ when compared with the blank specimen.
\end{abstract}

\section{INTRODUCTION}

The main raw materials of the alkali-activated materials are bulk industrial solid waste materials with a simple preparation technology, low energy consumption and little pollution, and they have partially replaced cement to be applied to the field of building materials at present as a typical energy-conserving low-carbon building material [1-2]. In addition, traditional solid wastes with stable properties like slag and coal ash have basically been utilised as a large-scale resource of building materials. Relative to the application situation featuring "the demands exceed the supply" of these solid wastes, the disadvantage of the steel slag, like the great difference in the properties and poor soundness due to the different sources have resulted in large difficulties with resource utilisation, and the comprehensive utilisation rate of the steel slag in China is only about $10 \%$. Therefore, to study the steel-slag based alkali-activated materials has favourable environmental, economic and social benefits, which can not only realise the resource utilisation of the steel slag as a building material and can turn waste into wealth, but also can realise low-carbon production and exert energy-conserving and emission reduction effects [3], and this is of positive significance to the sustainable development of the industry of building materials.

However, alkali-activated materials have significant shortcomings like poor volume soundness and easy efflorescence, which restricts their application to a certain degree [4-6]. Therefore, alkali-activated materials are faced with pressing modification requirements. Nano modification is an important approach to improve the properties of the binding materials by a large margin [7-8]. Technologies using nano materials to modify the binding materials started in developed countries in the 1970s and 1980s like America and several European countries, and a lot of research scholars have used nano materials to modify cement-based binding materials [9-11]. The author's early-stage research has found that during the matrix damage process of the binding material, pores will be produced and continuously expanded along the interface transition region of the hardening body and the two weak links of the binding material [12]. By virtue of ultrafine particle characteristics and high pozzolanic reactivity, nano $\mathrm{SiO}_{2}$ exerts physical filling and chemical bonding effects on the interface transition region and gel, and moreover, it can significantly improve 
the compactness of the cement-based binding material [13-14]. Meanwhile, it can rapidly weaken or consume the enrichment and directional alignment of $\mathrm{Ca}(\mathrm{OH})_{2}$ on the interface, increase the $\mathrm{C}-\mathrm{S}-\mathrm{H}$ content and reduce the $\mathrm{Ca} / \mathrm{Si}$ ratio of the hydration gel. The study shows that mixing a 5 wt. $\%$ of nano $\mathrm{SiO}_{2}$ can consume about $50 \%$ $\mathrm{Ca}(\mathrm{OH})_{2}$ while a 6 wt. $\%$ of $\mathrm{SiO}_{2}$ can reduce the $\mathrm{Ca} / \mathrm{Si}$ ratio by about $25 \%$ [8].

The alkali-activated material in the steel slag-granulated blast furnace slag system (abbreviated as alkaliactivated steel slag-slag material) was selected in this paper to study the effects of the nano $\mathrm{SiO}_{2}$ on the matrix compaction and efflorescence inhibition so as to enhance the advantages of the alkali-activated materials and modify or improve its disadvantages, so that it can be better applied to the field of building materials.

\section{EXPERIMENTAL}

\section{Experimental materials}

The steel slag used was from the Jigang Group Co., Ltd, China. The specific surface area of the steel slag after grinding was $330 \mathrm{~m}^{2} \cdot \mathrm{kg}^{-1}$, and the chemical composition is shown in Table 1. The slag used was from the Shandong Iron \& Steel Group Co., Ltd, its specific surface area was $440 \mathrm{~m}^{2} \cdot \mathrm{kg}^{-1}$, the chemical composition is seen in Table 2, and the particle size distributions of the steel slag and slag are shown in Figure 1.
The nano $\mathrm{SiO}_{2}$ used was from the Xuancheng Jingrui New Material Co., Ltd, and its average particle size was about $7-40 \mathrm{~nm}$, and the specific surface area was about $300 \mathrm{~m}^{2} \cdot \mathrm{g}^{-1}$. The modulus of the water glass which is used for alkali-activated reagent was $1.0\left(\mathrm{Na}_{2} \mathrm{O} \cdot \mathrm{nSiO}_{2}, \mathrm{n}=\right.$ $1.0)$.

\section{Experimental methods}

\section{Moulding method}

An appropriate amount of the nano $\mathrm{SiO}_{2}$ was placed in an ultrasonic cleaner which was added with the appropriate quantity of water, and it was dispersed under ultrasound for $5 \mathrm{~min}$. The steel slag and slag were weighed according to the matching ratio. The mixture was blended under a dry state in mixing pan, and then the dispersed nano $\mathrm{SiO}_{2}$ was poured into the mixing pan while the water glass was added. After moulding, it was transferred to a standard curing room for curing with the temperature being $20 \pm 2^{\circ} \mathrm{C}$ and the relative humidity being $\geq 90 \%$.

\section{Compressive strength}

The compressive strengths of specimens with the moulding size being $20 \times 20 \times 20 \mathrm{~mm}$ were determined when reaching the specified curing age. Loaded at $4 \mathrm{kN} \cdot \mathrm{s}^{-1}$, the average value of the 6 specimens was taken as the final testing result, and the value of the compressive strength of each specimen was accurate to $0.01 \mathrm{MPa}$.

Table 1. Chemical composition of the steel slag wt. \%.

\begin{tabular}{lccccccccc}
\hline Item & $\mathrm{CaO}$ & $\mathrm{MgO}$ & $\mathrm{Fe}_{2} \mathrm{O}_{3}$ & $\mathrm{Al}_{2} \mathrm{O}_{3}$ & $\mathrm{SiO}_{2}$ & $\mathrm{TiO}_{2}$ & $\mathrm{MnO}$ & Loss & Others \\
\hline Content & 43.74 & 7.36 & 20.21 & 5.71 & 13.8 & 0.88 & 4.39 & 1.20 & 4.39 \\
\hline
\end{tabular}

Table 2. Chemical composition of the slag wt. \%.

\begin{tabular}{lccccccccc}
\hline Item & $\mathrm{CaO}$ & $\mathrm{MgO}$ & $\mathrm{Fe}_{2} \mathrm{O}_{3}$ & $\mathrm{Al}_{2} \mathrm{O}_{3}$ & $\mathrm{SiO}_{2}$ & $\mathrm{TiO}_{2}$ & $\mathrm{MnO}$ & Loss & Others \\
\hline Content & 35.53 & 10.41 & 0.29 & 16.36 & 32.31 & 0.32 & 0.32 & 1.72 & 2.74 \\
\hline
\end{tabular}

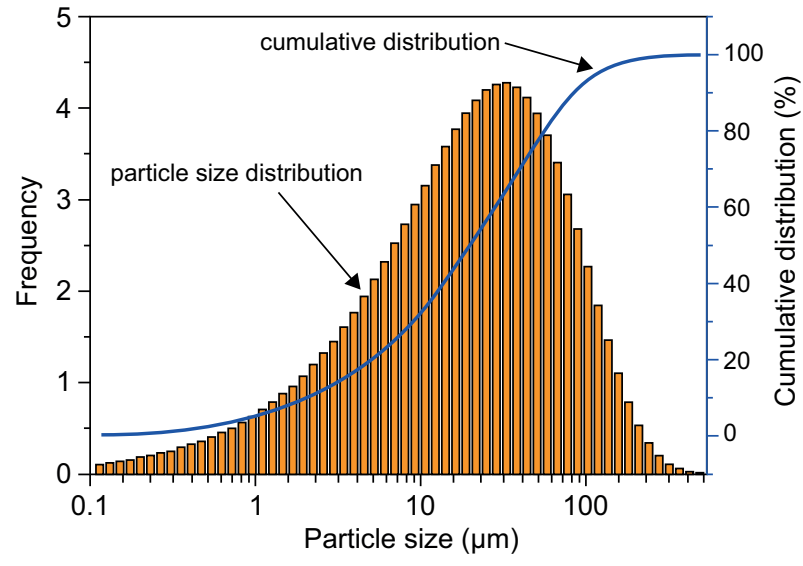

a) Steel slag

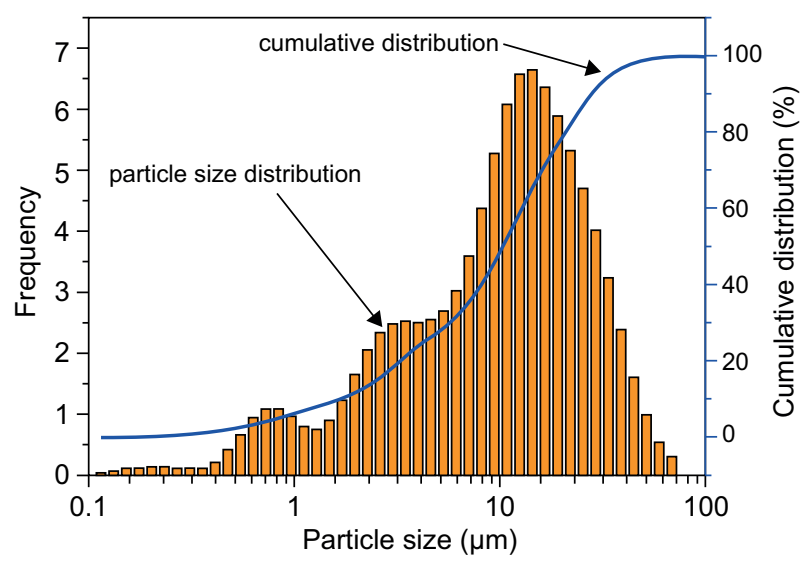

b) Slag

Figure 1. Particle size distribution graph of the steel slag and slag. 


\section{Efflorescence test}

The specimens cured to $28 \mathrm{~d}$ were soaked in $250 \mathrm{ml}$ distilled water for $48 \mathrm{~h}$, and the $10 \mathrm{ml}(V)$ leaching solution was taken and diluted to $50 \mathrm{ml}$. The $50 \mathrm{ml}$ solution after dilution was placed in a $150 \mathrm{ml}$ conical flask. Firstly, 3 drops of phenolphthalein was dropwise added into the conical flask as a colour indicator, and the prepared diluted hydrochloric acid (mole concentration $C_{\mathrm{HCl}}$ ) was added into the phenolphthalein to make it turn from red to colourless. The volume $V_{1}$ of the hydrochloric acid consumed at the moment was recorded. Then a new dropper was used to drip 3 methyl orange drops in the conical flask as a colour indicator, and the diluted hydrochloric acid was continuously titrated. When the solution turned from yellow to orange, the volume $V_{2}$ of hydrochloric acid consumed at the moment was recorded. The titration process was repeated 3 times in each group and the data was recorded. Concentrations of carbonate or bicarbonate radical ions were computed according to Equation 1, and the average value was used to characterise the efflorescence degrees of the geological polymer specimens.

$$
C\left(\mathrm{HCO}_{3}^{-} / \mathrm{CO}_{3}^{-}=\frac{V_{2} \times C_{\mathrm{HCl}}}{V}\right.
$$

where $V_{2}$ is the volume of hydrochloric acid consumed when methyl orange is used as the indicator. $C_{\mathrm{HCl}}$ is the molar concentration of the hydrochloric acid. $V$ is the solution volume $(10 \mathrm{ml}) . C\left(\mathrm{HCO}^{-} / \mathrm{CO}_{3}{ }^{2-}\right)$ is the molar concentration of the efflorescence ions $\left(\mathrm{mol} \mathrm{l}^{-1}\right)$.

\section{Others}

The water-binder ratio (W/B) and boiling soundness were determined according to GB/T 1346-2011 Inspection Method of Water Requirement of Normal Consistency of Cement, Setting Time and Soundness. The pressure-steaming soundness was determined according to GB/T 750-1992 Test Method of Cement Pressuresteaming Soundness.

The microtopographies of the specimens were observed using a Guanta FEG 250 FESEM from the US FEI Corporation, and the porosities were tested using a Pore Master 60GT mercury injection apparatus from the US Quantachrome Apparatus Corporation.

\section{RESULTS AND DISCUSSION}

Effect of the steel slag-slag mass ratio on the soundness

As shown in Table 3, the steel slag-slag mass ratio of the specimens in the 6 groups were different, the mixing amounts of $\mathrm{Na}_{2} \mathrm{O} \cdot \mathrm{SiO}_{2}$ were all $6 \mathrm{wt} . \%$, and the water-binder ratios were all 0.30 . The boiling soundness and pressure-steaming soundness methods were used to determine the soundness of the alkali-activated materials. The boiling soundness test results showed that specimen soundness in group A1 was unqualified while those in the other groups were all qualified, and the pressuresteaming soundness test results are shown in Figure 2.

The results in Figure 2 showed that as the mixing amount of steel slag reduced, the expansion rate of alkali-activated steel slag-slag material also reduced. When the mixing amount of the steel slag reduced to 60 wt. \%, the expansion rate was below the acceptance line, and this showed that the soundness was basically qualified, but the error bar showed that some specimens were still unqualified. Therefore, the boiling soundness and pressure-steaming soundness test results were combined to analyse the mass ratio of the steel slag and the slag was selected as $50 \%: 50 \%$ in order to ensure the qualification of the soundness of the alkali-activated steel slag-slag.

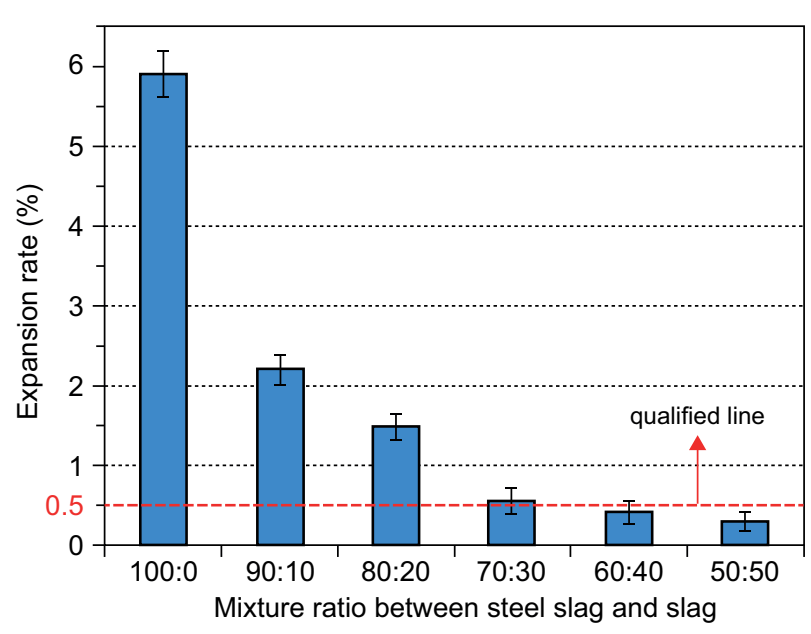

Figure 2. Effect of the steel slag-slag ratio on the pressuresteaming soundness of the alkali-activated materials.

Table 3. Effect of the steel slag-slag ratio on the soundness of the alkali-activated materials.

\begin{tabular}{lcccccc}
\hline No. & $\begin{array}{c}\text { steel slag } \\
\text { (wt. \%) }\end{array}$ & $\begin{array}{c}\text { slag/wt. \% } \\
\text { (wt. \%) }\end{array}$ & $\begin{array}{c}\mathrm{Na}_{2} \mathrm{O} \cdot \mathrm{SiO}_{2} / \text { wt. } \% \\
\text { (wt. \%) }\end{array}$ & W/B & $\begin{array}{c}\text { boiling } \\
\text { soundness }\end{array}$ & $\begin{array}{c}\text { pressure-steaming } \\
\text { soundness }\end{array}$ \\
\hline A1 & 100 & 0 & 6 & 0.30 & unqualified & unqualified \\
A2 & 90 & 10 & 6 & 0.30 & qualified & unqualified \\
A3 & 80 & 20 & 6 & 0.30 & qualified & unqualified \\
A4 & 70 & 30 & 6 & 0.30 & qualified & unqualified \\
A5 & 60 & 40 & 6 & 0.30 & qualified & qualified \\
A6 & 50 & 50 & 6 & 0.30 & qualified & qualified \\
\hline
\end{tabular}


Effect of the nano $\mathrm{SiO}_{2}$ on the compressive strength

Figure 3a showed that the mixing of the nano $\mathrm{SiO}_{2}$ had a significant effect on the compressive strength of the alkali-activated steel slag-slag material. The compressive strength of the specimen increased as the mixing amount of the nano $\mathrm{SiO}_{2}$ increased. When the mixing amount was $2.0 \%$, the compressive strength of specimen reached the maximum value, and the 1 day compressive strength reached $32.71 \mathrm{MPs}$ and the 28 days compressive strength reached $67.43 \mathrm{MPa}$, but as the mixing amount of nano $\mathrm{SiO}_{2}$ continued to increase, the compressive strengths in different periods reduced, but were still greater than that of the blank specimen, and this showed that the nano $\mathrm{SiO}_{2}$ could significantly improve the compressive strengths of the alkali-activated steel slag-slag material in the different periods. Figure $3 \mathrm{~b}$ shows that after the mixing of the nano $\mathrm{SiO}_{2}$, the 1 day compressive strength of the alkali-activated steel slagslag material had a higher growth rate than those in the other periods relative to the blank specimen. When the mixing amount of the nano $\mathrm{SiO}_{2}$ was $2 \%$, the growth rates of 1 day, 3 days, 7 days and 28 days compressive strengths were $203.71 \%, 37.97 \%, 87.91 \%$ and $39.29 \%$, respectively. The early-stage promoting effect of the nano $\mathrm{SiO}_{2}$ on the strength of the alkali-activated steel slag-slag material was obvious, and the promoting effect was gradually weakened as time went by. The specimen strength was closely related to the generation amount of the matrix hydration products and porosity, namely the more hydration products, the better the development of hardened structural body, the smaller the matrix porosity, and the specimen would have a higher compressive strength. After mixing the $\mathrm{SiO}_{2}$, it rapidly reacted with the alkali ions in the solution to generate a silicon structural body-precursor of a geological polymer, and the precursor concentration rapidly rose. Then the precursor reacted with $\mathrm{Ca}^{2+}$ in the liquid stage

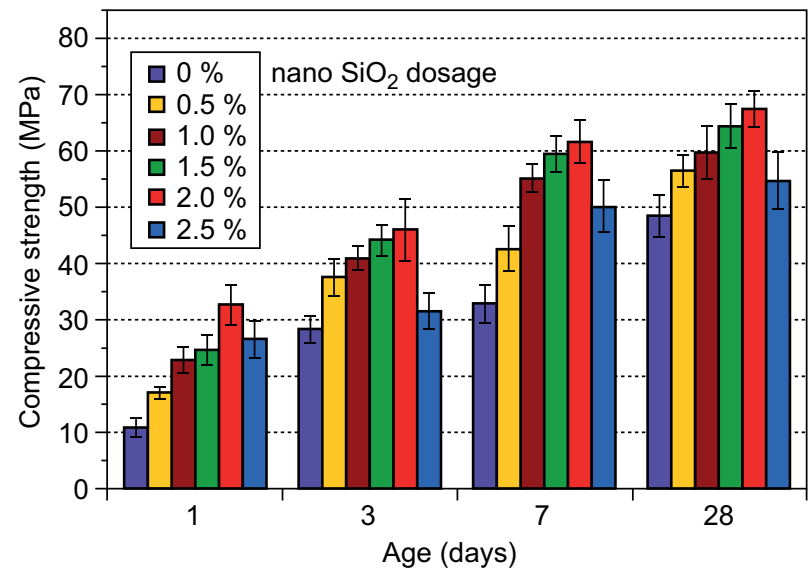

a) Compressive strength to generate the $\mathrm{C}-\mathrm{S}-\mathrm{H}$ gel which could fill the pores in the hardened slurry to exert the compacting effect on the matrix so as to improve the compressive strength of the specimen [15-16]. When the mixing amount of the nano $\mathrm{SiO}_{2}$ exceeded $2.0 \%$, the decline in the compressive strength was caused by the absorption of more moisture in the solution by the excessive nano $\mathrm{SiO}_{2}$ particles, which hindered the hydration progress of the hardened body and affected the normal development of the structure of the hardened body. More pores were formed in the matrix so that the specimen strength was affected [17-18].

\section{Effect of the nano $\mathrm{SiO}_{2}$ on the hydration}

\section{Hydration rate and hydration heat}

It could be seen from Figure 4 that the mixing of the nano $\mathrm{SiO}_{2}$ accelerated the hydration of the alkaliactivated steel slag-slag material with an increasing heat release, especially, the hydration rate prior to $1 \mathrm{~d}$ was obviously increased. One of the main reasons was that the nano $\mathrm{SiO}_{2}$ particles had a large specific surface area with high reactivity, which accelerated the hydration reaction, especially the early-stage hydration reaction $[3,19]$. Another reason was that the mixing of the nano $\mathrm{SiO}_{2}$ provided more nucleating points and accelerated the reaction in the dissolution and hydration stages [20]. And this was also the reason why the nano $\mathrm{SiO}_{2}$ could significantly improve the compressive strength of the alkali-activated steel slag-slag material, especially the early-stage compressive strength.

\section{Hydration products and microtopography}

It could be seen from Figure 5a that in the early hydration stage, some hexagonal block-shaped $\mathrm{Ca}(\mathrm{OH})_{2}$ was formed through the precipitation of calcium ions. But $\mathrm{Ca}(\mathrm{OH})_{2}$ was not found in Figure 5b, and this showed

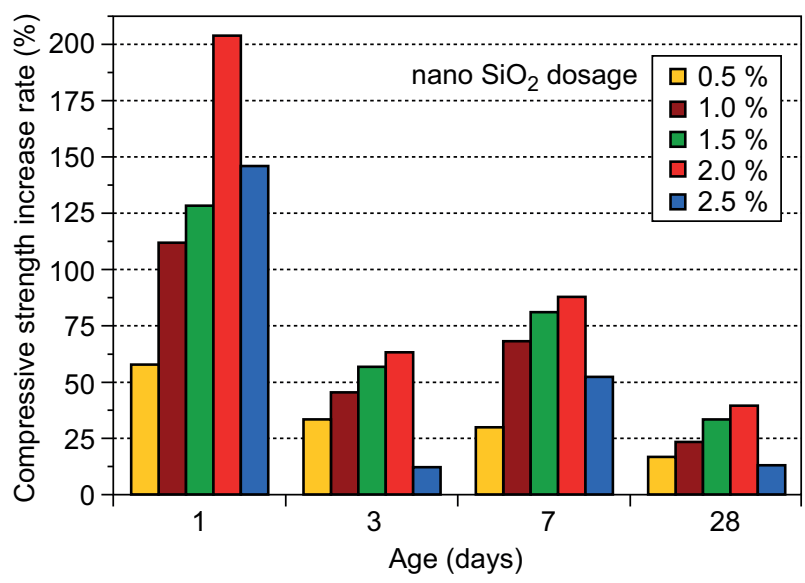

b) Compressive strength rate of increase

Figure 3. Effect of the nano $\mathrm{SiO}_{2}$ on the compressive strength and the growth rate of the alkali-activated steel slag-slag material. 
Efflorescence inhibition of alkali-activated steel slag-slag material by nano $\mathrm{SiO}_{2}$

that the generated amount of $\mathrm{Ca}(\mathrm{OH})_{2}$ was small after mixing the nano $\mathrm{SiO}_{2}$, because the nano $\mathrm{SiO}_{2}$ consumed $\mathrm{Ca}(\mathrm{OH})_{2}$ to generate more $\mathrm{C}-\mathrm{S}-\mathrm{H}$ gel and accelerate the hydration.

In addition, it could be seen from Figure 5 that compared with the blank specimen, after mixing the nano $\mathrm{SiO}_{2}$, a large quantity of clustering gel particles was generated in the hydration products, especially for the 28 days specimens, the clustering fibrous $\mathrm{C}-\mathrm{S}-\mathrm{H}$ gel was generated around the nano $\mathrm{SiO}_{2}$. Moreover, no matter to the time of 1 day or 28 days, the matrix phases of the specimens mixed with the nano $\mathrm{SiO}_{2}$ were obviously

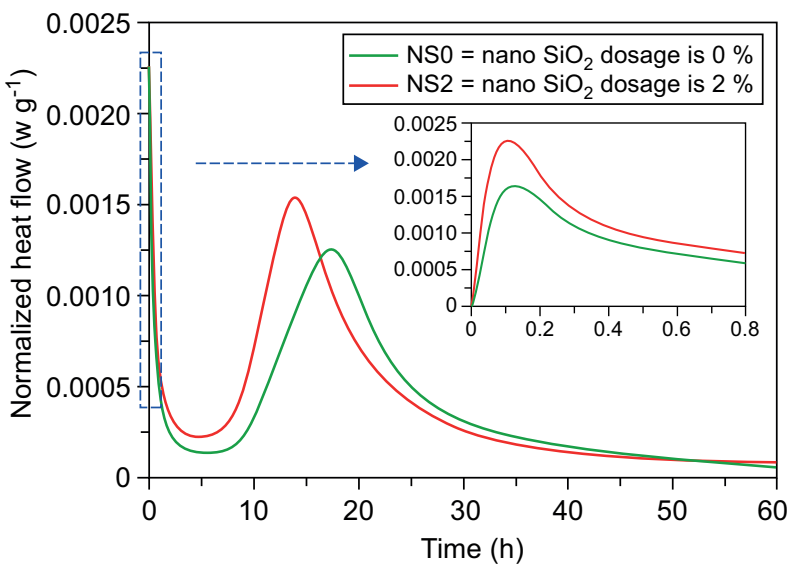

a) Hydration rate

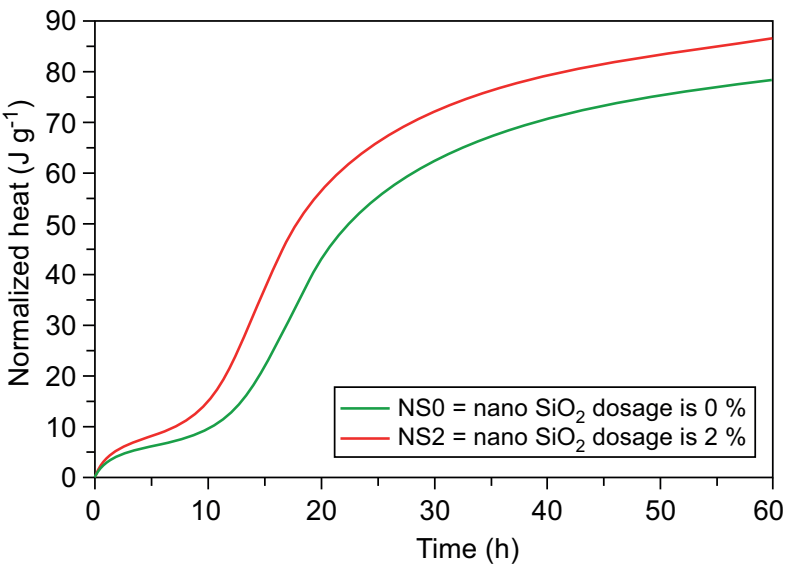

b) Hydration heat

Figure 4. Effect of the nano $\mathrm{SiO}_{2}$ on the hydration of the alkali-activated steel slag-slag material.

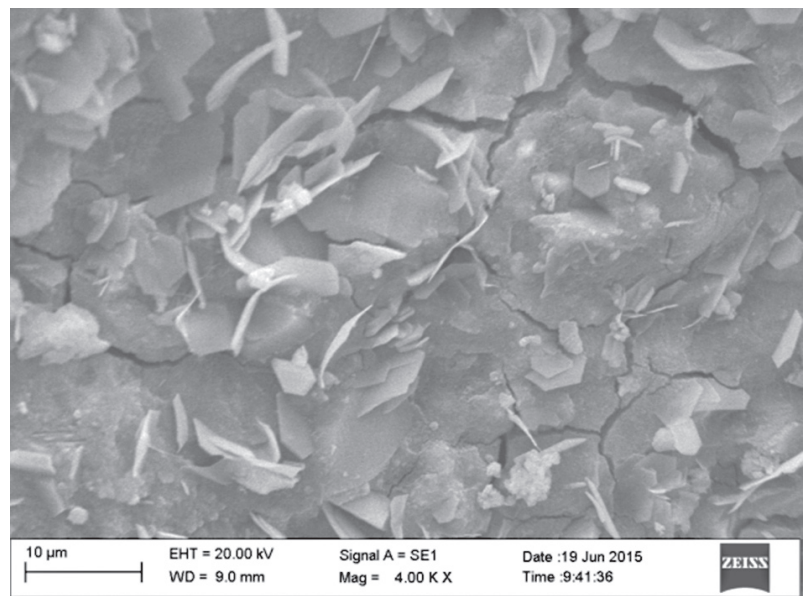

a) NS0 1 day

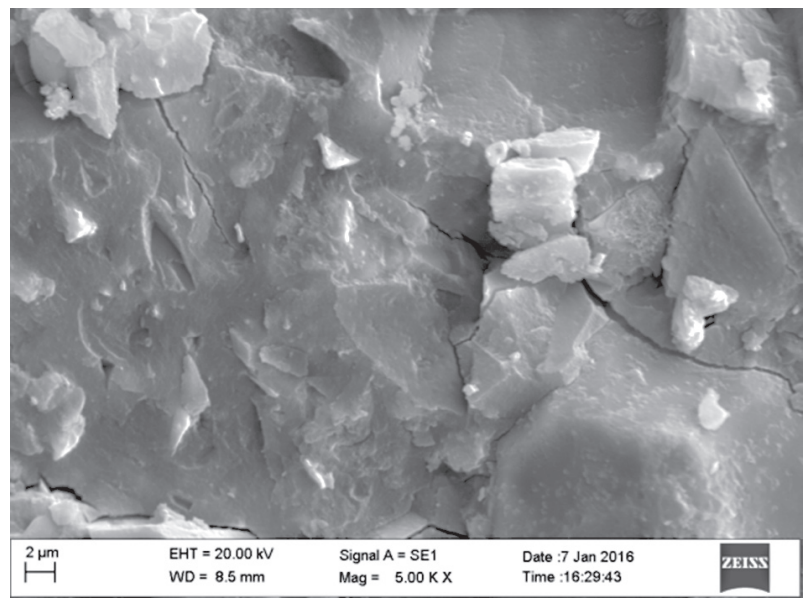

c) NS0 28 days

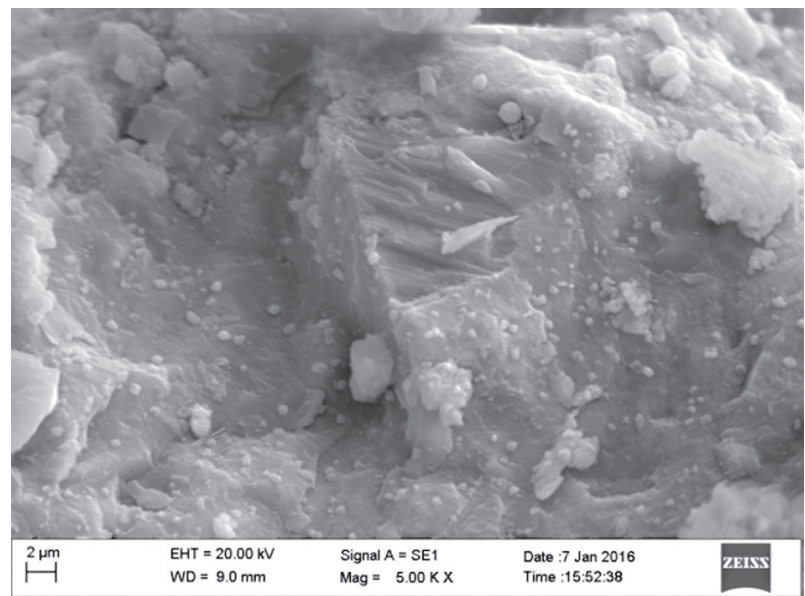

b) NS2 1 day

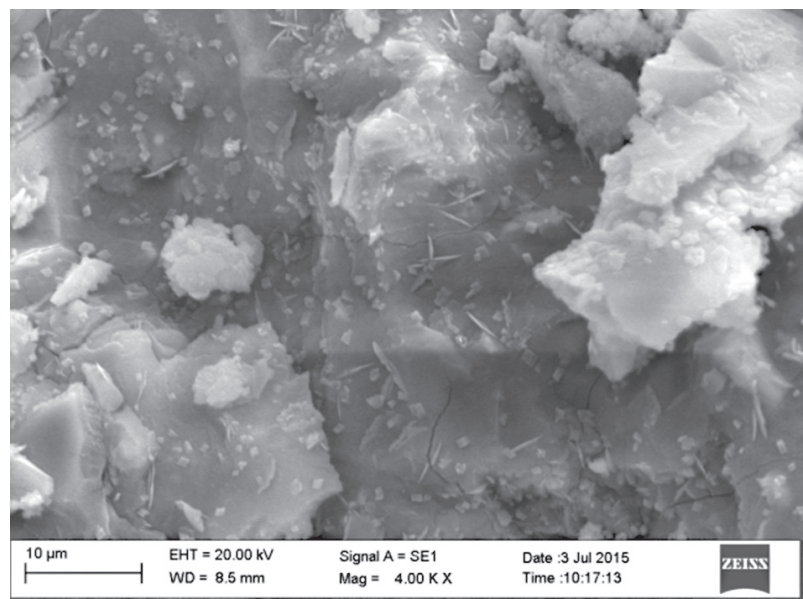

d) NS2 28 days

Figure 5. Comparative analysis of the specimens mixed with the nano $\mathrm{SiO}_{2}$ and the blank specimen. 
more compact than that of the blank specimen with fewer pores. Because mixing the nano $\mathrm{SiO}_{2}$ could exert the effect of a crystal nucleus, it facilitated the reaction on the surface of the nano $\mathrm{SiO}_{2}$ particles, and filled and cemented more pores and interfaces. The gel content increased with the mixing of the nano $\mathrm{SiO}_{2}$, which further compacted the matrix.

\section{Effect of the nano $\mathrm{SiO}_{2}$ on the porosity}

It could be seen from Figure 6 that mixing the nano $\mathrm{SiO}_{2}$ mainly influenced the pore diameter distribution and the pore content inside specimens, the nano materials could make diameters of undamaged pores $(<20 \mathrm{~nm})$, tiny damaged pores $(20-200 \mathrm{~nm})$ and damaged pores $(>200 \mathrm{~nm}$ ) transfer to small pore diameters, mixing the nano $\mathrm{SiO}_{2}$ made the total porosity reduce from $23.78 \%$ to $16.72 \%$ (by $7.06 \%$ ), which was possibly caused by the filling effect of fine nano $\mathrm{SiO}_{2}$ particles. Porosity was an important index characterising the specimen compactness and influenced the specimen properties like strength and efflorescence, and the lower the porosity, the higher the specimen strength, and the smaller the efflorescence degree. The greater the porosity, the better it is for the alkali ions inside the specimens to leach onto specimen surface with moisture, which would result in a serious specimen efflorescence degree.

\section{Efflorescence inhibition by the nano $\mathrm{SiO}_{2}$}

Surface efflorescence refers to the surplus alkali inside the material which is leached onto the material surface through pores in a liquid form of hydroxides and reacts with $\mathrm{CO}_{2}$ in the air as shown in Equations 2 and 3:

$$
\begin{gathered}
\mathrm{CO}_{2}(\mathrm{~g})+2 \mathrm{OH}^{-}(\mathrm{aq}) \rightarrow \mathrm{CO}_{3}{ }^{2-}(\mathrm{aq})+\mathrm{H}_{2} \mathrm{O} \\
\mathrm{CO}_{3}{ }^{2-}(\mathrm{aq})+\mathrm{CO}_{2}(\mathrm{~g})+\mathrm{H}_{2} \mathrm{O} \rightarrow 2 \mathrm{HCO}_{3}{ }^{-}(\mathrm{aq})
\end{gathered}
$$

This is caused by white carbonate or bicarbonate precipitates generated by a combination of $\mathrm{CO}_{3}{ }^{2-}$ and $\mathrm{HCO}_{3}^{-}$with alkali ions $\left(\mathrm{Na}^{+}, \mathrm{Ca}^{2+}\right.$ etc. $)$. Therefore, improving the pore structure of the material can inhibit efflorescence to a certain degree [17]. It could be seen from Figure 7 that when the mixing amount of the nano $\mathrm{SiO}_{2}$ was $0,0.5 \%, 1 \%, 1.5 \%, 2 \%$ and $2.5 \%$, the ionic concentration was $0.1354 \mathrm{~mol} \cdot 1^{-1}, 0.1266 \mathrm{~mol} \cdot \mathrm{l}^{-1}$, $0.1032 \mathrm{~mol} \cdot \mathrm{l}^{-1}, \quad 0.094 \mathrm{~mol} \cdot \mathrm{l}^{-1}, \quad 0.075 \mathrm{~mol} \cdot \mathrm{l}^{-1}$ and $0.0903 \mathrm{~mol} \cdot \mathrm{l}^{-1}$, respectively. As the mixing amount of the nano $\mathrm{SiO}_{2}$ increased, its inhibiting effect on the efflorescence of the alkali-activated steel slag-slag material firstly presented an increasing and then a decreasing trend. When the mixing amount of the nano $\mathrm{SiO}_{2}$ was $2 \%$, the ionic concentration of the leaching solution of the specimen reduced by $32.57 \%$ when compared with that of the blank specimen, mainly because the crystal nucleus and filling effects of the nano $\mathrm{SiO}_{2}$ would result in increasing hydration products generated by the specimen, on the one hand, the nano $\mathrm{SiO}_{2}$ particles would fill pores so that porosity would reduce and it would be difficult for alkali ions to leach out of the surface. On the other hand, the nano $\mathrm{SiO}_{2}$ would consume more of the hydration product $\mathrm{Ca}(\mathrm{OH})_{2}$ and more clustering fibrous $\mathrm{C}-\mathrm{S}-\mathrm{H}$ gels were generated around the nano $\mathrm{SiO}_{2}$, which effectively hindered the leaching channel of the alkali ions [20]. When excessive nano $\mathrm{SiO}_{2}$ particles were mixed, the nano particles absorbed more moisture in the solution, hindered the hydration process of the hardened body and affected the normal development of the structure of the hardened body, and consequently, the porosity increased and the alkali ions would easily be diffused from the pores to form the whitening phenomenon. Therefore, mixing an appropriate amount of nano $\mathrm{SiO}_{2}$ could inhibit efflorescence of the alkaliactivated steel slag-slag material to a certain degree.

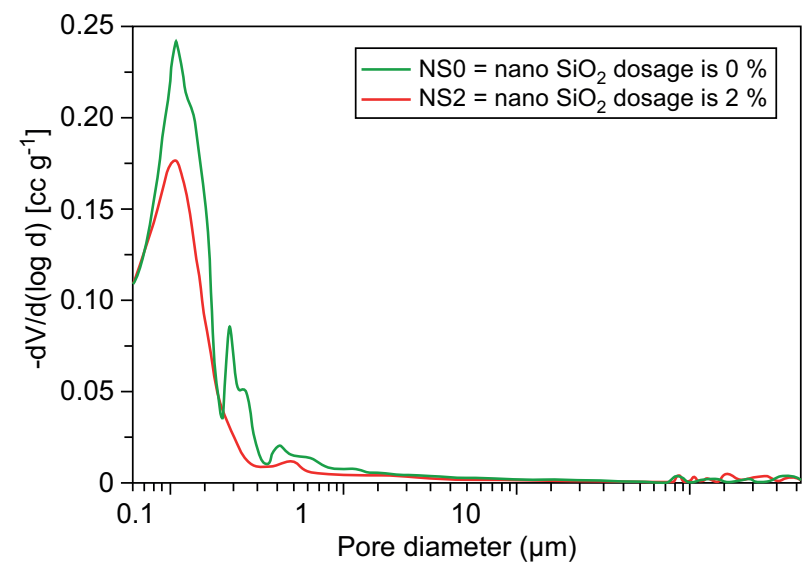

Figure 6. Effect of the nano $\mathrm{SiO}_{2}$ on the porosity of the alkaliactivated steel slag-slag material.

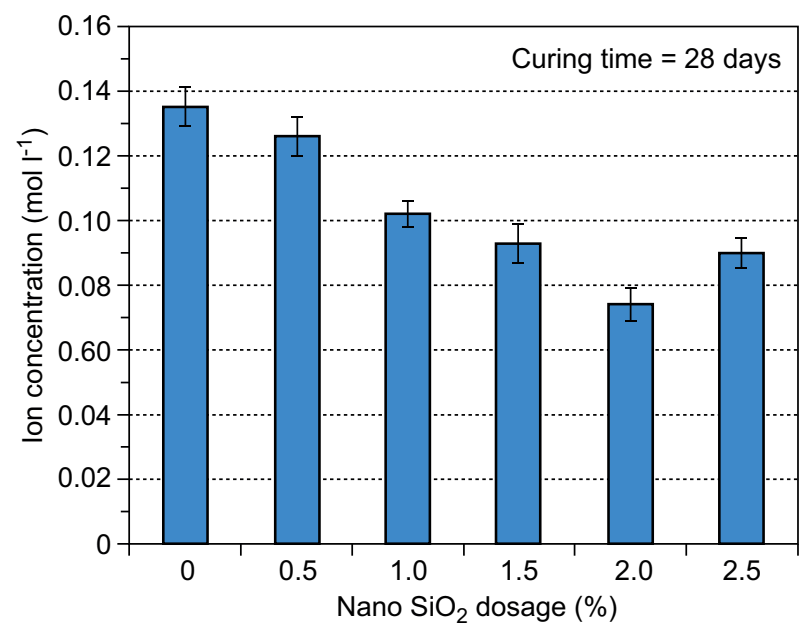

Figure 7. Effect of the nano $\mathrm{SiO}_{2}$ on the concentration of the efflorescent ions. 


\section{CONCLUSIONS}

Under certain conditions, the steel slag-slag mass ratio was determined to be $50 \%: 50 \%$ by combining the boiling soundness and the pressure-steaming soundness test results in order to ensure the qualified soundness of the alkali-activated steel slag-slag material.

The mixing of the nano $\mathrm{SiO}_{2}$ could significantly improve the compressive strength of alkali-activated steel slag-slag, especially the early-stage compressive strength. When the mixing amount was $2.0 \%$, the compressive strength of the specimen reached a maximum value and the 1 day and 28 days compressive strengths reached $32.71 \mathrm{MPa}$ and $67.43 \mathrm{MPa}$, respectively, with the growth rates being $203.71 \%$ and $39.29 \%$ relative to the blank specimen.

It could be known from the hydration heat and the SEM test results that the mixing of the nano $\mathrm{SiO}_{2}$ accelerated the hydration of the alkali-activated steel slag-slag material with an increasing heat release, the hydration before $1 \mathrm{~d}$ was especially obviously accelerated. In the early hydration stage, the mixing of the nano $\mathrm{SiO}_{2}$ consumed the hydration product $\mathrm{Ca}(\mathrm{OH})_{2}$ to generate more $\mathrm{C}-\mathrm{S}-\mathrm{H}$ gels and accelerate the hydration. In later hydration stage, the mixing of the nano $\mathrm{SiO}_{2}$ exerted the effect of the crystal nucleus, clustering fibrous $\mathrm{C}-\mathrm{S}-\mathrm{H}$ gels were generated around the nano-particles, and increasing the hydration products compacted the matrix and filled and cemented more pores and interfaces.

It could be seen from the porosity and efflorescence test results that the mixing of the nano $\mathrm{SiO}_{2}$ could improve the porous structure of the alkali-activated steel slag-slag material. The mixing of $2 \%$ nano $\mathrm{SiO}_{2}$ reduced the total porosity from $23.78 \%$ to $16.72 \%$ (by $7.06 \%$ ), which contributed to the leaching of alkali ions inside the specimen onto the surface to a certain degree. When the mixing amount of the nano $\mathrm{SiO}_{2}$ was $2 \%$, the ionic concentration of the leaching solution from the specimen reduced to $0.075 \mathrm{~mol}^{-1} \mathrm{l}^{-1}$ by $32.57 \%$ when compared with the ionic concentration in the blank specimen.

\section{Acknowledgements}

Support from the National Natural Science Foundation of China (Grant No. 51702121 and No. 51602126) and the 111 Project of International Corporation on Advanced Cement-based Materials (Grant No. D17001) is greatly acknowledged.

\section{REFERENCES}

1. Shi C., Jiménez A. F., Palomo A. (2011): New cements for the 21st century: the pursuit of an alternative to Portland cement. Cement and Concrete Research, 41(7), 750-763. doi: 10.1016/j.cemconres.2011.03.016

2. Gao X., Yuan B., Yu Q. L., Brouwers H. J. H. (2017): Characterization and application of municipal solid waste incineration (MSWI) bottom ash and waste granite powder in alkali activated slag. Journal of Cleaner Production, 164, 410-419. doi: 10.1016/j.jclepro.2017.06.218

3. Rashad A. M. (2013): A comprehensive overview about the influence of different additives on the properties of alkaliactivated slag-a guide for civil engineer. Construction and Building Materials, 47, 29-55. doi: 10.1016/j.conbuildmat. 2013.04.011

4. Shi, C., Roy, D., \& Krivenko, P. (2005). Alkali-activated cements and concretes. Taylor \& Francis Ltd.

5. Puertas F., Santos R., Alonso M. M., Del Rio M. (2015): Alkali-activated cement mortars containing recycled claybased construction and demolition waste. CeramicsSilikáty, 59, 202-210.

6. You D., Fang Y., Zhu C., Gong Y., Gu Y. (2016): Preparation and Properties of alkali-activated cement containing phosphorous slag and fly ash. Ceramics-Silikáty, 60(1), 63-67.

7. Kawashima, S., Hou, P., Corr, D. J., \& Shah, S. P. (2013). Modification of cement-based materials with nanoparticles. Cement and Concrete Composites, 36, 8-15. doi: 10.1016/j. cemconcomp.2012.06.012

8. Hou P., Kawashima S., Kong D., Corr D. J., Qian J., Shah S. P. (2013): Modification effects of colloidal nanoSiO $\mathrm{Si}_{2}$ on cement hydration and its gel property. Composites Part B: Engineering, 45(1), 440-448. doi: 10.1016/j.compositesb. 2012.05.056

9. Oltulu M., Şahin R. (2011): Single and combined effects of nano- $\mathrm{SiO}_{2}$, nano- $\mathrm{Al}_{2} \mathrm{O}_{3}$ and nano- $\mathrm{Fe}_{2} \mathrm{O}_{3}$ powders on compressive strength and capillary permeability of cement mortar containing silica fume. Materials Science and Engineering: A, 528(22-23), 7012-7019. doi: 10.1016/j. msea.2011.05.054

10. Yang L. Y., Jia Z. J., Zhang Y. M., Dai J. G. (2015): Effects of nano-TiO2 on strength, shrinkage and microstructure of alkali activated slag pastes. Cement and Concrete Composites, 57, 1-7. doi: 10.1016/j.cemconcomp. 2014.11.009

11. Phoo-ngernkham T., Chindaprasirt P., Sata V., Hanjitsuwan S., Hatanaka S. (2014): The effect of adding nano- $\mathrm{SiO}_{2}$ and nano- $\mathrm{Al}_{2} \mathrm{O}_{3}$ on properties of high calcium fly ash geopolymer cured at ambient temperature. Materials \& Design, 55, 58-65. doi: 10.1016/j.matdes.2013.09.049

12. Du P., Yao Y., Wang L., Xu D. Y., Zhou Z. H., Huang S. F., Cheng X. (2016): Deformation of a concrete matrix subject to a cyclic freeze-thaw process. RSC Advances, 6(63), 58417-58425. doi: 10.1039/C6RA01472K

13. Li G. (2004): Properties of high-volume fly ash concrete incorporating nano- $\mathrm{SiO}_{2}$. Cement and Concrete Research, 34(6), 1043-1049. doi: 10.1016/j.cemconres.2003.11.013

14. Behfarnia K., Rostami M. (2017): Effects of micro and nanoparticles of $\mathrm{SiO}_{2}$ on the permeability of alkali activated slag concrete. Construction and Building Materials, 131, 205-213. doi: 10.1016/j.conbuildmat.2016.11.070

15. De Silva P., Sagoe-Crenstil K., Sirivivatnanon V. (2007): Kinetics of geopolymerization: role of $\mathrm{Al}_{2} \mathrm{O}_{3}$ and $\mathrm{SiO}_{2}$. Cement and Concrete Research, 37(4), 512-518. doi: 10.1016/j.cemconres.2007.01.003

16. De Silva P., Sagoe-Crenstil K. (2008): Medium-term phase stability of $\mathrm{Na}_{2} \mathrm{O}-\mathrm{Al}_{2} \mathrm{O}_{3}-\mathrm{SiO}_{2}-\mathrm{H}_{2} \mathrm{O}$ geopolymer systems. Cement and Concrete Research, 38(6), 870-876. doi: 10.1016/j.cemconres.2007.10.003

17. Zuhua Z., Xiao Y., Huajun Z., Yue C. (2009): Role of water in the synthesis of calcined kaolin-based geopolymer. 
Applied Clay Science, 43(2), 218-223. doi: 10.1016/j. clay.2008.09.003

18. Gomez-Zamorano L. Y., Vega-Cordero E., Struble L. (2016): Composite geopolymers of metakaolin and geothermal nanosilica waste. Construction and Building Materials, 115, 269-276. doi: 10.1016/j.conbuildmat.2016.03.002

19. Jang J. G., Lee N. K., Lee H. K. (2014): Fresh and hardened properties of alkali-activated fly ash/slag pastes with superplasticizers. Construction and Building Materials, 50,
169-176. doi: 10.1016/j.conbuildmat.2013.09.048

20. Weng L., Sagoe-Crentsil K. (2007): Dissolution processes, hydrolysis and condensation reactions during geopolymer synthesis: Part I-Low Si/Al ratio systems. Journal of Materials Science, 42(9), 2997-3006. doi: 10.1007/s10853006-0820-2 